Brief Communication

Comunicação Breve

Milene Rossi Pereira Barbosa ${ }^{1}$ Fernanda Dreux Miranda Fernandes ${ }^{1}$

Keywords

Autistic Disorder

Language

Parent-child Relations

Social Communication

Behavior
Correspondence address:

Milene Rossi Pereira Barbosa

Departamento de Fisioterapia,

Fonoaudiologia e Terapia Ocupacional,

Faculdade de Medicina, Universidade

de São Paulo - USP

Rua Cipotânea, 51, Vila

Universitária, São Paulo (SP), Brazil,

CEP: 05360-000.

E-mail: milenefono@yahoo.com.br

Received: June 23, 2016

\section{Remote follow-up to speech-language intervention for children with Autism Spectrum Disorders (ASD): parents' feedback regarding structured activities}

\begin{abstract}
Purpose: This paper aims to present the first descriptions of experiences of parents and caretakers of children with Autism Spectrum Disorders (ASD) enrolled as mediators in a structured program of speech-language intervention with remote follow-up. Methods: Research with focus on speech-language intervention for children with ASD was carried out with remote follow-up. Forty parents were instructed to perform daily activities focused on communication and interaction with their children, at home, for a period of six weeks. Parents and caretakers were questioned about the experience and by means of a structured questionnaire. Results: Only $40 \%$ of the parents/caretakers conducted the activities proposed every day. Difficulties were reported by $60 \%$ of the parents/caretakers. Behavioral problems were also reported as reasons for the difficulties to conduct the activities proposed. Conclusion: the importance of parents who provide detailed information about the child's development, discuss doubts and exchange experiences for the development of intervention programs that include families.
\end{abstract}

Study carried out at Departamento de Fisioterapia, Fonoaudiologia e Terapia Ocupacional, Faculdade de Medicina, Universidade de São Paulo - USP - São Paulo (SP), Brazil.

${ }^{1}$ Universidade de São Paulo - USP - São Paulo (SP), Brazil.

Financial support: CNPQ.

Conflict of interests: nothing to declare. 


\section{INTRODUCTION}

Recent epidemiological reports point out that the prevalence of Autism Spectrum Disorders (ASD) is of 1 out of 88 children living in the USA ${ }^{(1)}$. These new figures indicate an increase of $78 \%$ in the prevalence of ASD over the last five years.

According to the previous version of the $\mathrm{APA}^{(2)}$ Diagnostic and Statistical Manual of Mental Disorders - DSM-IVtr, the category of pervasive Developmental Disorders refers to those characterized by severe and pervasive impairments in several areas of development, such as reciprocal social interaction, communication abilities and stereotyped behaviors, interests, and activities.

The diagnostic criteria for ASD proposed by the new version, DSM- $5^{(3)}$, include pervasive deficits in social communication and interaction in multiple contexts - including social-emotional reciprocity, disorders in non-verbal communication, difficulties in social relationships, repetitive and restricted patterns of behavior, interests, and activities - stereotyped movements, insistence in sameness, adherence to rigid routines, ritualized verbal and non-verbal patterns, restricted interests that are abnormal in focus or intensity, hyper- or hypo-reactivity to sensorial stimulus and/or uncommon interest in aspects of the environment.

The classification proposed by the DSM-5 doesn't affect the practice of speech-language pathology yet, as most diagnoses were performed before its publication. However, there will probably be a different group of children included in the autism spectrum within a few years.

All descriptions of ASD in children include important language disorders. The communication issue is probably one of the most significant impairments in ASD. The studies about language and communication of children with ASD that address the functional use of language usually make use of the linguistic parameters proposed by the Pragmatic theories ${ }^{(4,5)}$.

There is a wide variation among theoretical parameters that support therapeutic proposals for children with ASD, but the ultimate goals are the same: to improve social, cognitive and linguistic abilities ${ }^{(6)}$.

Most of the studies about language in children with autism focus on the child's communication ${ }^{(7,8)}$, while some focus on the mother/caretaker(CT)-child dyad, aiming to understand whether and how the role of the adult influences communication of children with $\operatorname{ASD}^{(9,10)}$.

Research points out that certain behaviors of adults may foster language and communication in children with $\mathrm{ASD}^{(11-13)}$; therefore, some intervention programs that seek to train parents and CTs as mediators in the therapeutic process are being developed.

Several studies have suggested that parents and CTs have a fundamental role in optimizing the development and promoting improvements in the social communication abilities of children with $\operatorname{ASD}^{(14,15)}$.

\section{OBJECTIVE}

To present the first descriptions of the experiences of parents and CTs of children with ASD enrolled as mediators in a structured program of speech-language intervention with remote follow-up.

\section{METHODS}

The work was referred to analysis by the Ethics Committee for Research Projects and was approved under Protocol 1.057.800. All adults responsible for the individuals involved signed the consent form.

Research with focus on speech-language intervention for children with ASD was carried out, with remote follow-up. Parents were instructed to perform daily activities focused on communication and interaction with their children, at home, during a period of six weeks. Parents and CTs were questioned about the experience and by means of a structured questionnaire. The questions asked were:

1- Was it difficult or impossible to perform the activity with you child on any particular day of the past week? Why?

2- What did you think about the proposed activity?

3- Do you have any suggestions about other activities or changes in the ones proposed?

4- How was play-time during this week? Did you have fun together?

5- Did you have any difficulty with the proposed activity?

6- Did any other family member participate in the activity? Who?

Participants were 40 parents of children with ASD aged between 6 and 17 years old. At this stage, they only received the intervention at home, having their parents as mediators. They were instructed to perform playing activities that have been planned and discussed with them before the onset of the program.

During the six-week period, the therapists contacted parents by means of the best or more easily available communication means established in advance (e-mail, telephone, Skype, Whatsapp). During these contacts, besides clarifying doubts and discussing the child's performance during the activities, the parents answered the questionnaire described, aiming to improve the next stage of the program.

\section{RESULTS}

Results indicate that only $40 \%$ of the parents/caretakers conducted the activities proposed every day. Among those who skipped the activities on a few days, $22.5 \%$ did so during weekends, $12.5 \%$ did so due to the adult's previous appointments, $10 \%$ reported that the child was sick, and another $10 \%$ that the child refused to participate.

The parents/CTs of $35 \%$ of the children participating in the program reported that the activities were difficult in at least one of the weeks of the program, while 5\% felt they were repetitive.

When asked about suggestions of new activities, 42.5\% proposed activities related to the children's interests and that were not included in the program, besides repeating some of the activities that had proven to be successful. 
The most significant result refers to the difficulties to conduct the activities at home. Some difficulties were reported by $60 \%$ of the parents/CTs. They described that they didn't understand the activity (5\%) or didn't have time, or that the child wasn't interested in playing. These reports call for consideration of strategies aimed to increase the parent's awareness about their role in the child's development, the importance of sharing activities and playing experiences with their child, and the need for flexibility in order to obtain the child's interest in certain activities, or even changing them according to the child's interest.

Behavioral problems were also reported as reasons for the difficulties to conduct the activities proposed. Attention impairments were described by $30 \%$ of the parents/CTs, as well as anxiety during the activity and tantrums at the end of it.

This proposal of speech-language intervention with remote follow-up allowed the inclusion of other family members besides parents/CTs. Only 11 children had always had the same adult as a playing partner during all of the activities. However, except for one child, the other adults were close family members. The exception was a neighbor that had very close contact with the child.

These data highlights the importance of parents for the development of intervention programs that include families by means of their provision of detailed information about the child's development, discussion of doubts and exchange of experiences. Speech-language pathologists should encourage and provide guidance for parents and caretakers to take more active roles in providing communication environments that are appropriate to children with ASD and that allow successful interactive experiences.

\section{REFERENCES}

1. CDC: Center for Disease Control and Prevention. US Department of Health and Human Services [Internet]. CDC estimates 1 in 88 children in United States has been identified as having an autism spectrum disorder [cited 2017 Jan 15]. Available from https://www.cdc.gov/media/releases/2012/ p0329_autism_disorder.html

2. APA: American Psychiatry Association. DSM-IV-TR: diagnostic and statical manual of mental disorders. 4th ed. Washington: APA; 2001.

3. APA: American Psychiatry Association. DSM -5: manual diagnóstico e estatístico de transtornos mentais. 5. ed. Porto Alegre: Artmed; 2014.

4. Fernandes FDM. Aspectos funcionais da comunicação de crianças com síndrome autística [tese]. São Paulo (SP): Universidade de São Paulo, Faculdade de Filosofia, Letras e Ciências Humanas; 1995. 207 p.
5. Fernandes FDM. Terapia de linguagem em crianças com transtornos do espectro autístico. In: Ferreira LP, Befi-Lopes DM, Limongi SCO, organizadores. Tratado de fonoaudiologia. São Paulo: Editora Roca; 2004. p. 941-53.

6. Lopes-Herrera SA. Avaliação de estratégias para desenvolver habilidades comunicativas verbais em indivíduos com autismo de alto funcionamento e Síndrome de Asperger [tese]. São Carlos (SP): Universidade Federal de São Carlos; 2004. 181 p.

7. Fernandes FDM, Barros CHC. Funções comunicativas expressas por crianças autistas: o uso de procedimentos específicos para inseri-las no contexto da terapia de linguagem. J Soc Bras Fonoaudiol 2001;2(6):45-54.

8. Molini DR, Fernandes FDM. Intenção comunicativa e uso de instrumentos em crianças com distúrbios psiquiátricos. Pró-Fono R Atual Cient 2003;15(2):149-58.

9. Borges LC, Salomão NMR. Aquisição de linguagem: considerações da perspectiva da interação social. Psicol Reflex Crit 2003;16(2):327-36. http://dx.doi.org/10.1590/S0102-79722003000200013.

10. Siller M, Sigman M. The behaviors of parents of children with autism predict the subsequent development of their children's communication. J Autism Dev Disord 2002;32(2):77-89. PMid:12058846. http://dx.doi. org/10.1023/A:1014884404276.

11. Siller M, Hutman T, Sigman M. A parent-mediated intervention to increase responsive parental behaviors and child communication in children with ASD: a randomized clinical trial. J Autism Dev Disord 2013;43(3):540-55. PMid:22825926. http://dx.doi.org/10.1007/s10803-012-1584-y.

12. Koegel RL, Bradshaw JL, Ashbaugh K, Koegel LK. Improving questionasking initiations in young children with autism using pivotal response treatment. J Autism Dev Disord 2014;44(4):816-27. PMid:24014174. http://dx.doi.org/10.1007/s10803-013-1932-6.

13. Ingersoll $B$. The differential effect of three naturalistic language interventions on language use in children with autism. J Posit Behav Interv 2011;13(2):10918. http://dx.doi.org/10.1177/1098300710384507.

14. Tonge B, Bull K, Brereton A, Wilson R. A review of evidence-based early intervention for behavioural problems in children with autism spectrum disorder: the core com-ponents of effective programs, childfocused interventions and comprehensive treatment models. Curr Opin Psychiatry 2014;27(2):158-65. PMid:24452070. http://dx.doi.org/10.1097/ YCO.0000000000000043.

15. Oono I, Honey EJ, McConachie H. Parent-mediated early intervention for young children with Autism Spectrum Disorders (ASD). Cochrane Database Syst Rev 2014;(4):CD009774. PMid:23633377.

\section{Author contributions}

All authors reviewed the final form of the paper and approved it for publication in the CoDASJournal. MRPB was responsible for data collection and literature review; FDMF was responsible for organizing, supervising and supervising the work. 